\title{
Deforestation Crimes and Conflicts in the Amazon
}

\author{
Tim Boekhout van Solinge
}

Published online: 17 September 2010

(C) Springer Science+Business Media B.V. 2010

\begin{abstract}
This article explores and explains deforestation of the Brazilian Amazon rainforest. It primarily takes a green criminological perspective and looks at the harm that is inflicted on many of the Amazon's inhabitants, including indigenous populations such as 'uncontacted' tribes of hunters-gatherers, the oldest human societies. The green criminological perspective also implies that the definition of victimisation is being enlarged: not only (future) humans, but also non-humans can be considered victims. Being the most biodiverse place on the planet, deforestation of the Amazon leads to threats and extinctions of animal and plant species. The main causes of deforestation in the Amazon are land conversion for agriculture (mainly cattle, also soy), practices that are mostly illegal. As the products of the (illegally) deforested rainforest in the Brazilian Amazon are mainly for export markets, western societies with large ecological footprints could be held responsible for deforestation of the Amazon.
\end{abstract}

\section{Pointing Arrows at an Airplane}

In May 2008, pictures of a small Amazonian tribe became world news. They were taken from an airplane flying over the Amazon in the border area of Brazil and Peru. It showed a dozen tribe members, mostly naked and painted red, around their thatched huts surrounded by dense Amazonian jungle. Some of the tribesmen were pointing arrows at the airplane from which the pictures were taken. Many newspapers and websites around the globe showed the pictures, usually accompanied by the news that they showed an undiscovered tribe in the Amazon rainforest.

The pictures were taken by Brazil's governmental Indian Affair Agency FUNAI, and were circulated by NGO Survival International. Peter Beaumont wrote in The Observer that the pictures had been presented as resulting from an "apparently chance encounter", while the tribe had been long known by the Brazilian government. This raised "awkward"

T. Boekhout van Solinge $(\bowtie)$

Willem Pompe Institute for Criminal Law and Criminology, Utrecht University, Utrecht,

The Netherlands

e-mail: t.boekhoutvansolinge@uu.nl 
questions over the decision to photograph them- "a form of contact in itself" (Beaumont 2008). That the tribe thus was not newly discovered, led some media to calling the pictures a hoax. Survival International reacted by saying it had not described the tribe as newly discovered: "What is, and remains, true, is that so far as is known these Indians have no peaceful contact with outsiders (Grudgings 2008)".

In the past the Brazilian government policy used to be to get in touch with 'uncontacted' tribes, but in more recent years the policy is to protectively isolate them. The Brazilian Indian Affairs Agency FUNAI, had decided to release the images "to call attention to fastencroaching development near the Indians' home in the dense jungles near Peru". FUNAI's Jose Carlos Meirelles, who took the pictures, declared: "We put the photos out because if things continue the way they are going, these people are going to disappear (Associated Press 2008)".

Some time before, Peru's President Alan Garcia had stated that "isolated Indians were a creation in the imagination of environmentalists and anthropologists" (Beaumont 2008). Garcia aimed to open up Peruvian jungle land for oil exploitation, logging, mining and large-scale farming (Boekhout van Solinge 2010). Publication of the pictures, however, led to pressure on the Peruvian government to act against logging near its border with Brazil, which conservationists say is the main threat to tribes living there (Grudgings 2008).

What will be the fate of the tribe that was photographed in 2008? Will it continue to exist? This particular tribe lived in the border area of Brazil and Peru, but illegal logging activities on the Peruvian side apparently forced it to seek refuge on the Brazilian side, in Acre state. Will it be safe there? Brazil's Acre state is not free from illegal logging either. Days before the pictures became world news, Brazil's environmental protection agency IBAMA announced it had shut down 28 illegal sawmills in Acre (Associated Press 2008). Although, for now, logging in this part of the Brazilian Amazon is relatively limited, loggers are closing in on the tribe's forest homeland. A new road that is being paved from Peru to Acre state will bring more loggers and settlers and will increase deforestation. Considering the increasing pressure on the rainforest in which tribes like this one live, it can be understandable that such tribes consider outsiders to mean trouble and wish to stay away from them, or chase them away with bows and arrows.

\section{The Study of (Illegal) Tropical Deforestation}

In handbooks of sociology and anthropology, societies of hunter-gatherers are described as the oldest forms of societies. What is hardly noted in these handbooks is that these old societies still exist, for instance in rainforests, but that many are threatened in their survival by deforestation.

The small tribe on the Peruvian-Brazilian border that sees the rainforests around them disappearing, exemplifies a phenomenon that can be observed all around the world. From the Amazon to South East Asia and Africa, traditional societies are being threatened by tropical deforestation. Many of these old societies live in tropical rainforests, the three largest of which are found along the equator: the Amazon basin, the Congo basin in Central Africa and on the tropical islands in South East Asia: Sumatra, Borneo and New Guinea. It is also exactly here that most of the last uncontacted tribes are living.

According to Survival International, there are about a hundred tribes around the world that avoid contact. Brazil is the country with most accounted but uncontacted tribes. According to FUNAI there are at least 68 uncontacted tribes in Brazil. The Brazil-Peru 
border area is one of the world's last refuges for such groups, with more than 50 uncontacted tribes thought to live there.

The island of New Guinea is the second most important place of uncontacted tribes. New Guinea is the world's second largest island and largest tropical island. It is divided between two States: the western side is Indonesia's province Papua, the eastern side is the State of Papua New Guinea (PNG). On both sides of the border traditional societies are being threatened by deforestation. New Guinea's dense and largely unknown forests are considered one of the world's most pristine natural places, inhabited by hundreds of indigenous groups, as well as by many rare or unknown animal species, such as various types of the bird of paradise and tree kangaroo. In recent years loggers have discovered New Guinea's financial forest potential, which has become the target of large-scale logging operations, especially for merbau, one of South East Asia's most valuable timbers, a darkred tropical hardwood twice as hard as oak (Boekhout van Solinge 2008c).

The Environmental Investigation Agency (EIA) and Indonesian NGO Telepak described how international criminal networks, formed by Malaysian businessmen, Indonesian military, and Chinese timber processing firms are illegally logging merbau in Papua and exporting it around the world (EIA and Telapak 2004, 2005, 2006). The eastern side of the island, PNG, also knows deforestation problems, which as explained by Gillison (2002: 134) come in two forms: "in the relatively unpopulated and roadless lowlands international logging interests, if left unchecked, will doubtless clear cut everything within their grab. But in the highlands the menace is not the companies behind the wave of machines eating the landscape; it is the slower but just as deadly tide of farmland expansion".

Generally speaking, it is not the traditional societies in rainforests that are mostly responsible for deforestation. That would not be in their self-interest, as they are dependent on the forest. No forest means no food, water and medicine. Forces from the outside are interested in the exploitation of rainforests: for their precious tropical hardwood, their relatively cheap soil (for agricultural use) or for the minerals and (precious) metals contained in the soil. Governments, businessmen and (multinational) companies see economic opportunities in tropical rainforests and aim at exploiting them.

Increased demand for relatively cheap rainforest land is particularly notable in large areas with relatively low human population density, where governmental presence and the control and enforcement of laws and regulations are often inappropriate. Due to corruption and the high profits of illegal tropical timber-which sometimes can be compared to those of the cocaine trade (Boekhout van Solinge 2008b: 61) - illegal logging is common in almost all tropical rainforests. It is a profitable illegal practice that is, nationally and internationally, hardly prosecuted (Boekhout van Solinge 2008a, c).

This article describes the mostly illegal deforestation of the Amazon rainforest. It addresses tropical deforestation as a harmful and criminological issue, primarily by taking a perspective of green criminology, the latest branch of criminology. As will be shown, the harm principle that is much used in green criminology (Beirne and South 2007; Sollund 2008; Kangaspunta and Marshall 2009; White 2010) applies well to tropical deforestation. Not only indigenous people, but many more other people as well experience harm as a result of tropical deforestation.

In a green criminological perspective as used here, the definitions of victimisation need to be extended. Beside humans, many non-humans are being threatened by tropical deforestation, because tropical rainforests contain more than half of the planet's biodiversity. In the words of biologist Edward Wilson, who introduced the term biodiversity: "The headquarters of global diversity are the tropical rainforests. Although they cover only about six percent of the land surface, their terrestrial and aquatic habitats contain more than 
half of the known species and organisms. They are also the leading abattoir of extinction, shattered into fragments that are then being severely adulterated or erased one by one" (Wilson 2002: 59).

Maybe the most shattering examples of animals being threatened by deforestation are humans' closest relatives, the great apes, living in the rainforests of Africa and Asia. All great apes - the chimpanzee, bonobo and gorilla in Africa, and Asia's only great ape, the orangutan-are seriously threatened by tropical deforestation. A second reason for their near extinction in the wild is commercial poaching, which is strongly stimulated and facilitated by logging and other types of deforestation (Boekhout van Solinge 2008b).

The geographical focus of this article will be the Amazon basin in South America, the world's largest rainforest. It is found around the American equator, with two-thirds of it within Brazil's borders (Goulding et al. 2003: 16). The Amazon is a place with many special inhabitants and where most 'uncontacted' tribal societies are (still) living. Its poor soils do not allow large leaf-eaters such as great apes but the Amazon is extremely rich in flora and fauna, containing $20-30 \%$ of the planet's biodiversity. One hectare of Amazon rainforest contains over 300 different tree species, a larger variety of trees than found in the whole of Europe. Each tree hosts a unique variety of animals and insects, with some trees hosting up to 1,500 species of insects (London and Kelly 2007: 24).

The mostly illegal deforestation of tropical rainforests around the world raises a number of questions. Tropical deforestation obviously creates much social and ecological harm. It not only causes human victims, as in the case of the disappearance of the oldest human societies, but also leads to ecological degradation, destruction and the disappearance of animal and plant species. While it thus seems relatively easy to identify the victims, would it also be possible to identify the people or forces that could be labelled as perpetrators, responsible for the harm that is being caused? In other words, what and who are the main causes and drivers of (illegal) deforestation of the Amazon rainforest?

Different research methods were used for this contribution. Part of the data used here derive from written sources: academic and journalistic publications, NGO reports and press articles. Qualitative methods, such as interviews and ethnographic fieldwork, were also used. Brazil's states Amazonas and Pará were visited in 2003, 2009, and 2010. Stakeholders were met or were interviewed, including timber traders, government officials, law enforcers, scholars, NGO's members, human right advocacy groups and members of forest communities. Moreover, visits were made to rainforests, including (illegally) deforested areas.

Using ethnographic methods in areas of tropical rainforests is not always easy and carries some safety risks for the researcher. Meeting people involved in deforestation activities may be dangerous and sometimes requires creativity, as they are not always willing to meet someone working in the field of (critical) criminology. As a measure of precaution, it is recommended that researchers investigating eco-crime in and around tropical rainforests, do not always (immediately) reveal their identity as criminological researchers. Although this may raise ethical questions, it seems sometimes-depending on whom one is speaking to- the only way to safely conduct research and gather information.

\section{A History of Encounters and Exploitation in the Amazon}

For a long time, until well into the late twentieth century, the idea was held that the Amazon was a relatively empty space, a desert with trees, like a "castle in the sand", as one influential writer on the Amazon put it (Meggers 1971: 158). It was dominant scientific 
thinking that the dense and inhospitable jungles of the Amazon rainforest could not support large human populations. Its relatively unfertile soil-as compared to the tropical rainforests of Africa and Asia-would not be able to support them. Only small tribes, such as hunters-gathers, could live there. Another dominant scientific idea was that the Amazon people were descendants from people from the Andes. Small groups would have descended from the mountains into the lower tropical rainforests. It was thought that South American civilization had drifted down from the north (having ancestors in Asia, who had crossed the Bering Strait) and that the skeletons found in Clovis, New Mexico (hence Clovis Man), were the forefathers of the South American tribes (London and Kelly 2007: 7).

More recent research conducted in the 1980s and 1990s, for example by Anna Roosevelt $(1989,1996)$, suggests that the Amazon has been inhabited several thousands years longer then previously thought. Anna Roosevelt is the great-granddaughter of US President Theodore Roosevelt who explored the interior of the Amazon almost a century ago, dying several years later after the Amazon had destroyed his health. Anna Roosevelt studied pottery with radiocarbon technology and concluded it was at least 6,000 years old, the oldest found in South America. Roosevelt also discovered, near a cave with old paintings, thousands of stone artifacts and other proof of human habitation, dated to be more than 10,000 years old. This suggests that the habitation of the Amazon is actually as old as Clovis Man (London and Kelly 2007: 5). Roosevelt's findings revolutionized scientific knowledge about the Amazon. The pre-Colombian indigenous population there is now thought to have been much older and more numerous than previously held.

Dense and impenetrable as the Amazon may seem, its population is not as isolated as outsiders may assume. Over the past 500 years, groups of outsiders have entered the Amazon, resulting in many generations of Indians having had encounters with the external world. As a general rule, these encounters were unpleasant for the indigenous population. They were taken as slaves, robbed, killed or infected by diseases to which they had no resistance.

The first outsiders were 'discoverers' and conquerors of South America, mainly Portuguese and Spanish, who hoped to find gold and silver. Intoxicated by the gold quest, after robbing the Incas in South America and the Aztecs in Central America, they explored the Amazon interior to find El Dorado, the Golden One, a king so rich he would cover himself with gold dust. One of the most famous Amazonian expeditions was that of 1541 led by Francisco de Orellana, who was joined by missionary Gaspar de Carvajal who kept a journal. They were the first Europeans to go from Quito (in today's Ecuador) all the way down to the Amazon River's mouth (near today's Belém in Brazil), a journey that took them eight months. Carvaljal described encountering "hundreds of canoes, each filled with twenty to forty Indians" (London and Kelly 2007: 17) near today's city Santarem (almost $1,000 \mathrm{~km}$ from the river's mouth). Historians long thought this was fantasy but now believe, based on archaeological findings, that thousands of people indeed were living there.

In the later period of African slavery a total of 10 million Africans were brought to the Americas, almost half of them to Brazil. Escaped slaves and their ancestors, looking for forest havens to live in, would sometimes have territorial conflicts with Indians. Slavery in Brazil was abolished in the late nineteenth century but this period attracted a new type of labour into the Amazon: rubber tappers.

The rubber boom that started by the end of the nineteenth century attracted many to the Amazon interior. At the time, rubber was only found in Central and especially South America, and gave much wealth to the Brazilian cities Belém and Manaus. Brazil lost much of this wealth after the first recorded act of bio-piracy in 1875, when Henry 
Wickham smuggled 70,000 rubber seeds from Brazil to Britain (Jackson 2008). Seeds were taken to the European colonies in Asia, where large rubber plantations were set up around the turn of the century. Unlike the rubber plantations in Asia, most rubber trees in the Amazon rainforest were not planted, but were growing in the wild. The trees thus had to be found. The Indians had used rubber for a long time but during the rubber boom, with rubber being exported worldwide, many remote corners of the Amazon rainforest were explored to find the precious trees. This led to clashes between the indigenous population and rubber tappers. It also meant that indigenous people, as well as poor migrants, were being exploited by rubber barons.

For the Amerindian population in general, the arrival of Europeans caused a demographic catastrophe. In the Amazon, the pre-Colombian population is estimated to have been seven million, with five million in the territory that today is Brazil. As a result of the European arrival, invasions and conquests, the indigenous population was literally decimated. Many died from illnesses they had no defence against such as influenza, common colds, and smallpox.

Today, the indigenous population in Brazil is around half a million. Of the more than twenty million Brazilians who now inhabit the Amazon, the indigenous population is thus by far in the minority. The number of uncontacted tribes has strongly reduced. In the 1960s, there were some 250 indigenous tribes thought to be living in Brazil beyond contact with modern society (London and Kelly 2007: 35). As mentioned before, their numbers today are estimated at 68 tribes, a more than $70 \%$ reduction in less than 40 years.

The outside dangers of diseases brought by foreigners are far from over. It still occurs that when tribe members meet people from the outside, a substantial part of the tribe is wiped out in a short period of time, due to lack of immunity to common diseases such as flu. Fifty percent of a tribe may die in months after first contact (Associated Press 2008). Other diseases are also brought from the outside, especially hepatitis and tuberculosis (Interview Missionary Indigenous Council CIMI, Manaus, July 2009).

Another problem faced by indigenous populations in the Amazon is caused by outsiders wishing to exploit the rainforest. In many such cases, encounters between indigenous people and outsiders are not peaceful. As will be explained later, tribal populations, as well as other forest inhabitants, become victims of violent loggers and 'land grabbers', that is large landowners who wish to transform rainforest into agricultural land.

\section{Frictions in the Amazon}

Anna Lowenhaupt Tsing, in her book Friction, discusses deforestation in Indonesia and the friction arising out of the encounters of different cultures. "Something shocking started to happen in Indonesia's rainforests during the last decades of the twentieth century. Species diversity that had taken millions of years to assemble were cleared, burned, and sacrificed to erosion" (Tsing 2005: 2). In the 1970s, Indonesia's tropical rainforests started to be harvested as industrial timber for the world market, first for Japan, later also for Europe and North America. By 1973, Indonesia was the world's largest tropical timber exporter (ibid p. 14).

The often used term globalisation remains somewhat abstract but Tsing, through her concept of friction, shows how globalisation works in practice. As she explains, friction makes global connections powerful and effective but it is a lie that global power operates as a well-oiled machine. To explain her concept of friction, Tsing uses the metaphor of a wooden stick. One stick alone is just a stick, but rubbing two sticks together produces heat 
and light. "As a metaphorical image, friction reminds us that heterogeneous and unequal encounters can lead to new arrangements of culture and power". The effects of friction are not always negative. "Hegemony is made as well as unmade with friction" (Tsing 2005: 5). The destruction of Indonesia's rainforests also led to the rise of, sometimes unexpected, environmental movements.

While Tsing focused on Indonesia's rainforests in Kalimantan, the Indonesian part of Borneo, episodes like a tribe's encounter with outsiders in an airplane in Brazil's Acre state, are also an example of what Tsing means by friction. Another example, also from Acre state, was the growing tension between rubber tappers and ranchers during the 1970s and especially 1980s. In the 1960s and 1970s, ranchers arrived in this part of the Amazon, putting fire to rainforest to turn it into pasture land (Mendes 1989). Although the crimes and violence committed by the ranchers were destructive, they also had a positive effect in the sense that they eventually led to more international attention and awareness.

There was (and is) an almost natural friction between rubber tappers and ranchers. Large landowners wish to clear rainforest in order to turn it into pastureland for their cattle. The rubber tappers on the other hand, wish to preserve rainforest. The interest of the rubber tapper obviously is the rubber tree. As most rubber trees in the Amazon grow in the wild, rubber tappers need the forest for their livelihood. Installing rubber plantations as in Asia, is difficult in the Amazon, as in most areas the poor soils do not allow many of the same tree species to grow near each other. ${ }^{1}$

In the 1980s, there were increasing tensions between ranchers and rubber tappers in the State of Acre, where pastureland was expanding at the expense of the rainforest and consequently the rubber tappers' livelihood. One rubber tapper, Chico Mendes, started organizing rubber tappers in unions:

Seen as the indefatigable organizer of the impoverished and as a troublemaker by the ranchers, Mendes had organized rural workers in empates, standoffs on land used but not owned by rubber tappers. The rubber tappers' sworn enemies, the ranchers, in many instances also did not legally own the land. But the ranchers had the means to corrupt public officials who 'certified' their ownership, and the ranchers hired gunmen who enforced those certifications (London and Kelly 2007: 43).

When Chico Mendes was killed in 1988 by the son of a rancher, he became an international icon for the protection of the Amazon rainforest. Mendes became a martyr. His murder led to a wave of international attention for the Amazon rainforest, which took Brazilian policy makers by surprise. Brazil's Amazon rainforest was now the international focus of attention. It temporarily led the Brazilian government to stop subsidies for cattle farms in the Amazon.

In retrospect it is interesting to see how a relatively unknown rubber tapper killed in the Amazon could achieve such stature. London and Kelly (2007: 44) give some explanations. "For the first time, an issue emerged from the jungle with a human element. Not only were trees dying, but people were dying, too. (...) His death reminded the world that there were millions of people living in the Amazon". 1988 was also a time when much forest was being lost in the Amazon. In 1987, some $80,000 \mathrm{~km}^{2}$ had been burned; in the state of

\footnotetext{
1 This is why in dense tropical rainforests such as the Amazon with little wind, trees primarily make use of animals for their reproduction. It is not in the interest of a tree to have its species nearby, as they would compete over the same nutrition. Animals however can bring seeds over large distances (Tudge 2006: 343-344). In the Amazon, with 5-6\% of the forests being flooded part of the year, sometimes several meters high, fish also spread seeds. One Amazonian fish in particular, the tambaqui, eats the large rubber seeds.
} 
Roraima alone $40,000 \mathrm{~km}^{2}$ in one month (ibid. 40), an area comparable to The Netherlands. Farmers usually set fire to the forest in August or September, when the rainforest is dry enough to burn. Moreover, what scientists had been warning about, now also appeared in newspapers: the releasing into the air of large quantities of carbon (from the rainforest's biomass) might be warming up the atmosphere. This long-ignored hypothesis began to receive attention. London and Kelly further note there were circumstances outside Brazil that facilitated international attention on the destruction of the Amazon. In the USA, 1988 had the hottest summer in decades. During this hot North American summer, South America's Amazon forests were burning again. The two were easily combined and related. "The planet was heating up, and to lose the Amazon would be to lose our lung capacity: a global suffocation, the theory went (ibid. 40)".

That the Amazon is like a lung of the planet is not true. Although it is thought to be true by many, this rainforest actually absorbs as much oxygen as it produces. Algae in the oceans are much more important for the production of oxygen. That the planet is heating up however, and that the burning rainforests contribute to this, seems increasingly indisputable.

The murder of Chico Mendes resulted in much international attention and functioned as a international wake up call of the different harms, including murder, that tropical deforestation in the Amazon is causing. The destruction and preservation of the Amazon were also on the international political agenda. Political leaders from Europe and the USA suggested placing the Amazon under international sovereignty.

Many Brazilians see this as an intrusion into their internal affairs. They argue that the Americans and Europeans have logged most of their forests, which enabled them to develop economically. Now that Brazilians wish to do the same, richer westerners are saying they are not allowed to. A Brazilian viewpoint is that in order to compete with the heavily subsidized American and European agriculture, Brazil needs to exploit its forests.

\section{Crimes and Victims in the Brazilian Amazon}

Mendes' murder and the consequent international concern over deforestation in the Amazon could not prevent deforestation, combined with violence, from continuing. That Mendes was killed by the son of a rancher is, in a sense, not atypical. Ranchers, often large landowners, regularly have conflicts with people who resist deforestation. This regularly results in murder and other types of violence inflicted against forest populations or protectors of the environment.

Another, more recent example is the murder of American-born Sister Dorothy. In 2005 she was killed in the Brazilian state Pará, where she was protecting the rainforest and the poor. She had previously received death threats from loggers and landowners. As in the case of Mendes, after a series of trials and appeals, a rancher was convicted for ordering the murder, while another was convicted for hiring gunmen to kill her. The latter had, apparently, been mentioned in letters Sister Dorothy had sent to the authorities, accusing him of illegally setting fire to forest to clear land. ${ }^{2}$

Sister Dorothy was killed in the state of Pará, where the large Amazon river flows into the ocean. Pará state is known for its lawlessness, illegal deforestation, land grabbing and land conflicts. Two years before the murder, Greenpeace International (2003), in a welldocumented report, described Pará as a "State of Conflict". The Brazilian Pastoral Land

\footnotetext{
${ }^{2}$ On the Internet (Wikipedia, Youtube, etc.) information can be found about Sister Dorothy, her work, her murder, and details of the different trials.
} 
Commission CPT (2009), the best-informed Brazilian NGO about these matters, documented Pará as the state that has most land conflicts.

Besides land conflicts over deforestation for timber and pastureland, a growing number of conflicts have arisen over soy cultivation. Over the last years they have occurred especially near the city of Santarém, where the crystal blue clearwater river Tapajós flows into the muddy brown Amazon river, almost a 1,000 km from the river's mouth (It was in Santarém where Carvajal, in the sixteenth century, reported seeing hundreds of Indian canoes). As American soy giant Cargill constructed a soy export harbour terminal in Santarém in 2003 and the area has become attractive for soy cultivation. Large landowners from the south of Brazil buy or-more commonly_-grab land, which increasingly leads to land conflicts. As appeared from different interviews that were conducted in the area, such as with CPT representatives (in Santarém, February 2009), most of the deforestation is illegal and it is common that farmers use policemen or pistoleros, gunmen, to force traditional communities to leave the land. In some cases, the new 'landowners' show some paper work (which can be 'bought') to the mostly illiterate forest communities, as 'proof' that they are the new owners. Even in case the land is owned or leased legally, Brazil's federal laws oblige that $80 \%$ of the forest land remains and that a maximum of $20 \%$ is being deforested for agricultural purposes. These laws however, are hardly enforced, especially at the state level in Pará, and the new 'owners' often get away with deforesting most or the whole area.

In Jurutí, also along the Amazon River upstream from Santarém, near the adjacent state of Amazonas (where the rule of law is stronger, with consequently more rainforest remaining) there is another land conflict. This conflict is also related to the activities of an American multinational. Alcoa, the world's largest aluminium producer, is deforesting rainforest for bauxite. This deforestation is legal, because the Federal government approved it. Traditional forest communities, descendants of the Munduruku tribe, in total some 9,000 people living in different villages in the forest and along rivers and lakes, say they were not mentioned in Alcoa's environmental impact study. A forest community leader who was interviewed (in Santarém, February 2009) declared that Alcoa representatives offered some small financial compensation and gave some presents but for the forest communities this is far from enough. They see many important food and medicinal trees, sometimes several hundreds years old, disappear. Also, they fear that drinking water is and will be polluted, as much water is needed for the bauxite extraction. In January 2009, forest communities protested at the Alcoa plant in Jurutí. Hundreds of protestors arrived by boats, but armed riot police (from state capital Belém) protected the Alcoa plant and used teargas to chase the protestors away. So far, the protests of the forest communities near Jurutí have not been successful and have received no international media attention. It is an example of a mostly neglected conflict outside this part of the Amazon. Locally, the subject of the bauxite multinational divides opinion; some praise Alcoa for providing jobs, others say it destroys the rainforest.

In more general terms, conflicts and human rights violations are common in the Brazilian Amazon and all kinds of crimes are connected to deforestation. The Brazilian Amazon is a vast area with relatively low population densities and consequent low governmental presence and surveillance that is known for its low level of law enforcement. Applied to the rainforest, this means that most of the logging for timber, as well as most deforestation for land conversion (for agricultural purposes) is illegal. Greenpeace Brazil, which also has an office in the Amazon, situated in Manaus, capital of the Amazonas state, has developed expert knowledge about forestry issues. As big commercial interests are at stake, Greenpeace's office in Manaus has a sophisticated security entrance procedure, 
comparable to some countries' embassies. It has a high quality academic staff that monitors the forest situation in the Amazon, partly by using recent technologies. Staff of Greenpeace Brazil (interviewed in Manaus, in May 2009) estimate that 60-80\% of the total deforestation in the Brazilian Amazon is illegal.

In the western world it is often thought that logging for tropical timber is the main cause of deforestation in the Amazon. Land conversion however, turning rainforest into agricultural land, such as for cattle or soy, is a far more important cause. Deforestation for cattle and soy often go hand-in-hand in the Brazilian Amazon, for which reason authors speak of the beef-soy complex (Verweij et al. 2009).

Cattle ranching have provoked some $70 \%$ of deforestation of the Brazilian Amazon (Malhi et al. 2008: 169). Since 2003, Brazil has become the world's largest beef producer and exporter, surpassing the USA. The cattle herd has grown to the extent that Brazil now has more cows (200 million) than people (190 million). In the Brazilian Amazon, the proportion of cows to people is even higher: 70 million cows as compared to 20 million people. The cattle numbers have grown especially in the state of Mato Grosso and to a lesser extent in the state of Pará (Greenpeace Brazil 2009). The expansion of cattle ranching in the Brazilian Amazon has even led to a new term, "cattelization" (Verweij et al. 2009). As most of the deforestation, also for cattle, is illegal, the Brazilian term to designate this type of cattle is 'pirate steers'.

Some of the big cattle ranches (and also some sugarcane farms, for ethanol) in remote areas in the Amazon are associated with working conditions akin to slavery. Workers are kept in debt bondage and armed guards prevent them from leaving. The government fights this practice with a special heavily armed task force, established in 1995, that raids large farms and businesses. Every year, several thousand people are thus freed from slavery. Since 1995, 33,000 people have been freed, but estimates are that at least 25,000 Brazilians continue to toil in debt slavery conditions.

With most deforestation being illegal, a human population of millions and the ineffective rule of law and law enforcement, there are logically many human victims. Large landowners, loggers, miners and prospectors may see forest communities, rubber tappers, and protectors of the rainforest as a hindrance to their plans. It is not uncommon that people from forest communities are pushed or chased away by gunmen.

Indigenous populations are disproportionately victimised by deforestation. Although they are by far in the minority among the total human population in the Brazilian Amazon, the fact that they are often found at the bottom of Brazilian society (with those with European ancestry at the top), living in forests that others wish to exploit, means that they generally lose out and see their human rights abused. Moreover, given their low social status, some of the elitist landowners think that it is unreasonable and unnecessary that 'the Indians' get so much living space. Ranchers, loggers and prospectors use the same rationalization for the often-occurring illegal invasion and exploitation of Indian reserves.

CIMI, the Brazilian Missionary Indigenous Council, publishes annual reports detailing violence against indigenous people. The reports list a variety of crimes, including dozens of murders of indigenous adults and minors, by loggers, miners, ranchers or other land grabbers. Territorial conflicts, environmental damage of indigenous areas, violence against indigenous individuals and acts of racism are common (CIMI 2009). Another phenomenon threatening the Indian tribes is the high suicide rate among some of Brazil's indigenous peoples such as the Guarani-Kaoiwá in the state of Matto Grosso do Sul, known for its deforestation for soy and sugar cane. A relatively large number of young Indians commit suicide because they see no future for themselves without forest. In their view, it is better to commit suicide that to inflict harm on others. 
The few remaining uncontacted tribes, also fall victim to violence regularly. The official policy in Brazil is to protect indigenous populations such as uncontacted tribes. Large landowners, however, often do not like uncontacted Indians on the land they wish to exploit, as an Indian presence implies the forestland should be preserved. A landowner interested in this land may chase away uncontacted Indians or simply kill them, resulting in the forest being uninhabitated and ready for exploitation.

The fact that a tribe is called 'uncontacted', does not imply that it is totally ignorant about the outside world. Put differently, the fact that most people from modern societies are ignorant about societies of hunters-gatherers, does not mean they these old societies are ignorant about modern society. According to Bernardo Beronde, an anthropologist working in Acre state, where the 'uncontacted' tribe was photographed:

Almost all these tribes know about western civilization and have sporadic contact with prospectors, rubber tappers and loggers, but choose to turn their backs on civilization, usually because they have been attacked. It's a choice they made to remain isolated or maintain only occasional contacts, but these tribes usually obtain some modern goods through trading with other Indians (Associated Press 2008).

A group of victims of Amazonian deforestation that has not been much mentioned so far, are the many animal and plant species that live there. With an estimated 20-30\% of the planet's biodiversity found in the Amazon, deforestation obviously leads to a reduction and extinction of species. The famous nineteenth century naturalist Alfred R. Wallace (friend and colleague of Darwin) spent some years in the Amazon, mainly living in Santarém, Pará. Wallace suggested that the Amazon's diversity of animals and plants seemed to be determined by the many waterways, forming barriers that have, in evolutionary terms, led to a differentiation of species. Deforesting an area, therefore, almost automatically means that species are threatened and (may) become extinct.

How much of the Amazon has already been lost? By 2001, about $837,000 \mathrm{~km}^{2}$ of Amazon rainforest had been cleared. Of the total Amazon, some 20\% has now been deforested (London and Kelly 2007: 58). If $30 \%$ of the Amazon is deforested, this may be a tipping point, after which the climate in the Amazon may alter, with repercussions for the regional and maybe global climate, which possibly cannot be reversed (Verweij et al. 2009). Eighty percent of all Amazonian deforestation has taken place in Brazil. In the late 1980s, after Chico Mendes' murder, the deforestation rate in the Brazilian Amazon slowed down to an annual $10,000 \mathrm{~km}^{2}$. Between 1988 and 2006 as a whole, it averaged $18,100 \mathrm{~km}^{2}$. It increased in the $1990 \mathrm{~s}$, with some $20,000-25,000 \mathrm{~km}^{2}$ per year, mainly as a result of installing cattle ranches. Deforestation increased again in the beginning of this century, peaking in 2004 with $27,400 \mathrm{~km}^{2}$, the main cause being increased land conversion for soy cultivation. After 2004 deforestation gradually decreased to some 11,000 in 2007 (Malhi 2008: 169).

\section{Discussion: Who is Responsible?}

Species inhabiting our planet are disappearing at an unprecedented speed. Biologists speak of an extinction crisis, or the "sixth extinction" (Leakey and Lewin 1996). ${ }^{3}$ Between 1970 and 2005, a recent Science article shows, biodiversity continued to decline, with increasing

\footnotetext{
${ }^{3}$ In the history of the planet of several billion years, there have been five waves of mass extinction. We currently are at the beginning of the sixth.
} 
risks for species to becoming extinct (Butchart et al. 2010). These data appear in 2010, which the UN declared to be the international year of biodiversity. The rapid disappearance of tropical rainforests, as in the Amazon, at a speed of several football fields a minute, is of special concern because tropical rainforests house more than half of the earth's known species. Such rapid changes in the environment are likely to have repercussions for humans as well (Leakey and Lewin 1996). Edward Wilson (2002: 149-150) points at a new ethics that is needed in order to save the world's fauna and flora:

What humanity is inflicting upon itself and Earth is, to use a modern metaphor, the result of a mistake in capital investment. Having appropriated the planet's natural resources, we choose to annuitize them with a short-term maturity reached by progressive increasing payouts. (...) Why, our descendants will ask, by needlessly extinguishing the lives of other species, did we permanently impoverish our own?

One reason to preserve tropical rainforests, besides stewardship of the oldest human societies and the rich animal and plant kingdom, is that a quarter of our medicines come from them. This is old ethno-botanical knowledge which, sometimes through eco-piracy is being synthesised and commercialised by pharmaceutical industries (South 2007). As many plants are still scientifically and pharmaceutically unknown, destroying tropical rainforests also means destroying potential medicines.

Another reason why it is in the human interest to preserve tropical rainforests is associated with the need to limit emissions of greenhouse gasses. What was still new science in the 1980s, now seems scientifically established knowledge (also due to the work of the UN's IPCC). Tropical deforestation is found to be responsible for almost $20 \%$ of all greenhouse gasses, more than all transport (cars, boats and airplanes) combined. This means that all humans, and even more so, future generations, are potential victims of rainforest destruction. The UN has developed a recent plan (REDD) that allows paying for rainforest preservation. Billions are available, but the question is: who should be paid to guarantee that rainforests are preserved?

In order to conserve much of the planet's biodiversity, and to achieve greater "ecological justice" (White 2008), new perspectives are needed. One condition seems to be the realization of a new global ethics, such as the one proposed by Singer (2004). On a philosophical, ethical and economical level, this requires more ecological awareness and awareness of the harm that is currently inflicted on our living environment. The latter point should also be addressed from a green criminological perspective. Most criminology is still western-biased and predominantly preoccupied with common crimes such as theft, whereas in a global perspective much greater social and environmental harms are being inflicted outside the western world, particularly in the tropical regions (Boekhout van Solinge 2008b).

Finally, while the different harms and many different victims of tropical deforestation have been established, would it be possible to identify the perpetrators, the culprits? It is easy to blame Brazilians, or 'southern countries' with their higher level of corruption than northern countries. Some in western societies in the north, confronted with facts or images about tropical deforestation, point their finger at 'those' corrupt countries in the south: in Africa, South East Asia and Latin America. They say that illegal deforestation activities are occurring there, and should also be addressed there.

In the field of illegal drug markets, western countries in the north used to blame the drug producing countries for causing drug problems. The southern, 'producing' countries defended themselves by stating that the demand was coming from the north; blaming only the production side ignored the other side of the market. Since the late 1990s, it is common 
to speak of a shared responsibility and a balanced approach to both drug producing and consuming countries (see Boekhout van Solinge 2002).

The same way of reasoning can be applied to the destruction of tropical rainforests. It is too simple to blame Brazil, 'the Brazilians' or 'the Indonesians' for the deforestation of the rainforests in their countries and, of course, many people in these countries are worried about this destruction (e.g. Mello and Marigo 2007; ISA 2007; Tsing 2005).

Applying the concepts of shared responsibility and a balanced approach, it may be useful to look again at the main causes of tropical deforestation in the Amazon and elsewhere. This article has shown that land conversion, transforming rainforest into productive agricultural land for cattle and soy, has been the main cause of Amazonian deforestation over the last decades.

Where does all this meat and soy go? Brazil's beef and soy are primarily destined for export markets. Brazil has overtaken the USA as the world's largest beef and soy exporter. The beef, sometimes in tinned form, goes all over the world; primarily to the western world, Russia and the Arab countries (Egypt). Brazil has also become the largest leather exporter. The soy primarily goes to countries with large numbers of cattle, as the soy is mostly used to feed animals. Brazilian soy mainly goes to Europe and increasingly also to China. In Europe, The Netherlands is the largest importer. Most of it is exported further, but The Netherlands itself, with its intensive agriculture (cows, pigs, poultry), uses a quantity of soy that is grown on an area corresponding to half the country (Verweij et al. 2009).

Addressing deforestation in the Amazon therefore implies addressing western consumption patterns, which include large quantities of meat and dependence on certain industrially produced foods, as Pollan (2008) explained. This also means that the heavily subsidized agricultural industries and the large ecological footprints of some western regions (North America, Europe, Australia) should be addressed. It can be argued that those societies with large ecological footprints are actually mostly responsible for the destruction of ecosystems. Simply put: if everyone would like to live like Europeans, we would need two to three planets. Living like North Americans or Australians would require five planets. In the case of beef, leather and soy, products that partly derive from illegally deforested Amazon rainforest, the companies that buy and sell them could show corporate responsibility by guaranteeing the legal (and ideally sustainable) origin of these products. Consumers and consumer organisations could require similar guarantees in this respect. The issue of illegal tropical timber could and should also be addressed more, because half of the tropical timber in western countries is still of illegal origin (Boekhout van Solinge 2008a, c).

\section{Pointing Arrows at Whom?}

This article started with a story about photos of a small nomadic Amazonian tribe that was probably forced to flee from Peru as a result of illegal logging activities. Their arrows were pointed at people that they believe threaten them. As they need rainforests to live in, those destroying forests are the ones they see as culprits. In that sense, their arrows were also pointed at the people in the west, who have large ecological footprints through buying tropical hardwoods and eating much meat. Many of us, without realising, are complicit with the perpetrators of (illegal) deforestation in the Amazon.

Humanity's oldest societies such as hunters-gatherers in tropical rainforests do not destroy the environment in which they live. They respect their environment because it 
gives them food, water, shelter, and medicine. Advanced agricultural and industrial societies, however, do destroy their environments. Modern societies also destroy the environments of the oldest human societies that still exist. Without wanting to idealize the latter, the question can be rightfully raised which type of society is, in the end, the wisest.

\section{References}

Associated Press. (2008). Brazil reveals 'uncontacted' Amazon tribe. Government decides to release photos to alert world to threat to Indians. New York: Associated Press.

Beaumont, P. (2008). Secret of the 'lost' tribe that wasn't. The Observer. June 22, 2008.

Beirne, P., \& South, N. (Eds.). (2007). Issues in green criminology. Confronting harms against environments, humanity and other animals. Devon: Willan.

Boekhout van Solinge, T. (2002). Drugs and decision-making in the European Union. Amsterdam: Mets \& Schilt.

Boekhout van Solinge, T. (2008a). Eco-crime: The tropical timber trade. In D. Siegel \& H. Nelen (Eds.), Organized crime. Culture, markets and policies (pp. 97-111). Dordrecht: Springer.

Boekhout van Solinge, T. (2008b). Crime, conflicts and ecology in Africa. In R. Sollund (Ed.), Global harms. Ecological crime and speciesism (pp. 13-34). New York: Nova Science Publishers.

Boekhout van Solinge, T. (2008c). The land of the Orangutan and bird of paradise under threat. In R. Sollund (Ed.), Global harms. Ecological crime and speciesism (pp. 51-70). New York: Nova Science Publishers.

Boekhout van Solinge, T. (2010). Equatorial deforestation as a harmful practice and criminological issue. In R. White (Ed.), Global environmental harm. Criminological perspectives (pp. 20-36). Devon: Willan.

Butchart, S. H. M., et al. (2010). Global diversity: Indicators of recent declines. Science, 328, 1164-1168.

CIMI-Conselho Indigenista Missionário. (2009). Violência contra os povos indígenas no Brasil. Brasilia: CIMI.

CPT—Comissão Pastoral de Terra. (2009). Conflitos no campo Brasil 2008. Goiâna: CPT.

de Mello, T., \& Marigo, L. C. (2007). Amazonas. Patria da água-Amazonas Water Heartland. São Paulo: Editora Boccota. (publication in Portuguese and English).

EIA and Telapak. (2004). Profiting from plunder: How Malaysia smuggles endangered wood. London: EIA.

EIA and Telapak. (2005). The last frontier. Illegal logging in Papua and China's massive timber theft. London: EIA.

EIA and Telapak. (2006). Behind the Veneer: How Indonesia's last rainforests are being felled for flooring. London: EIA.

Gillison, D. (2002). New Guinea ceremonies. New York: Harry N. Abrams.

Goulding, M., Barthem, R., \& Ferreira, E. (2003). The Smithsonian Atlas of the Amazon. Washington \& London: Smithsonian.

Greenpeace Brazil. (2009). Amazon cattle footprint. Mato Grosso: State of destruction. Manaus/São Paulo: Greenpeace Brasil.

Greenpeace International. (2003). State of conflict. An investigation into the landgrabbers, loggers and lawless frontiers in Pará State, Amazon. Amsterdam: Greenpeace International.

Grudgings, S. (2008). Group denies misleading media over Amazon tribe, Reuters. Rio de Janeiro, 24 June 2008. http://www.reuters.com/article/latestCrisis/idUSN24332207.

ISA-Instituto Socioambiental. (2007). Almanaque Brasil Socioambiental 2008. São Paulo: ISA.

Jackson, J. (2008). The thief at the end of the World: Rubber, power, and the seeds of Empire. New York: Viking.

Kangaspunta, K., \& Marshall, I. H. (Eds.). (2009). Eco-crime and justice. Essays on environmental crime. Turin: UNICRI.

Leakey, R. E., \& Lewin, R. (1996). The sixth extinction. Patterns of life and the future of humankind. London: Weidenfeld and Nicolson.

London, M., \& Kelly, B. (2007). The last frontier. The Amazon in the age of globalisation. New York: Random House.

Malhi, Y., Timmons Roberts, J., Betts, R. A., Killeen, T. J., Li, W., \& Nobre, C. A. (2008). Climate change, deforestation, and the fate of the Amazon. Science, 319(5860), 169-192.

Meggers, B. J. (1971). Amazonia: Man and culture in a counterfeit paradise. Chicago: Aldine-Atherton.

Mendes, C. (1989). Fight for the forest. Chico Mendes in his own words. London: Latin America Bureau. 
Pollan, M. (2008). In defence of food. The Myth of nutrition and the pleasure of eating. London/New York: Penguin.

Roosevelt, A. C. (1989). Lost civilizations of the Lower Amazon. Natural History, 74-83.

Roosevelt, A. C., et al. (1996). Paleoindian Cave Dwellers in the Amazon: The peopling of the Americas. Science, 272(1996), 373-384.

Singer, P. (2004). One world. The ethics of globalization. New Haven \& London: Yale University Press.

Sollund, R. (Ed.). (2008). Global harms. Ecological crime and speciesism. New York: Nova Science Publishers.

South, N. (2007). The 'corporate colonisation of nature': Bio-prospecting, bio-piracy and the development of green criminology. In P. Beirne \& N. South (Eds.), Issues in green criminology: Confronting harms against environments, humanity and other animals. Devon: Willan.

Tsing, A. L. (2005). Friction. An ethnography of global connection. Princeton \& Oxford: Princeton University Press.

Tudge, C. (2006). The tree. A natural history of what trees are, how they live and why they matter. New York: Crown Publishers.

Verweij, P., Schouten, M., van Beukering, P., Triana, J., van der Leeuw, K., \& Hess, S. (2009). Keeping the Amazon forests standing: A matter of values. Zeist: WWF Netherlands.

White, R. (2008). Crimes against nature. Environmental criminology and ecological justice. Devon: Willan Publishing.

White, R. (Ed.). (2010). Global environmental harm. Criminological perspectives. Devon: Willan.

Wilson, E. O. (2002). The future of life. New York: Vintage (Random House). 